\title{
Does Environmental Innovation Produce License: A Customer-Based Brand Equity Perspective?
}

\author{
Qiong Yao*, Heng Fang \\ Management School, Jinan University, Guangzhou, China \\ Email: *yaoqiong@126.com, 35578576@qq.com
}

How to cite this paper: Yao, Q. and Fang, H. (2018) Does Environmental Innovation Produce License: A Customer-Based Brand Equity Perspective? American Journal of Industrial and Business Management, 8, 103128.

https://doi.org/10.4236/ajibm.2018.81007

Received: December 4, 2017

Accepted: January 16, 2018

Published: January 19, 2018

Copyright (c) 2018 by authors and Scientific Research Publishing Inc. This work is licensed under the Creative Commons Attribution International License (CC BY 4.0).

http://creativecommons.org/licenses/by/4.0/

\begin{abstract}
Firms often look for ways to improve the return on investment that they earn from costly environmental innovation. Drawing from customer-based brand equity perspective, this article investigates license effect, a previously unexplored benefit associated with brands' environmental innovation. License effect refers that high level of environmental innovation grants brands the license to employ atypical marketing strategy without penalty (in the form of impaired attitudes). We confirm the existence of license effect at product attribute level and brand level in study 1 and 2. Study 3 further investigated whether license effect was contingent on important contextual factors. Our results reveal that license takes effect on price strategy at both product attribute level and brand level. Moreover, license effect disappears in recycle phase. We conclude that license comes into effect only when customers construe atypical marketing strategies as behaviors that associated with personal benefit. By introducing license effect, we bridge innovation literature and customer-based brand equity theory to explore firms' benefit from consumers' evaluations. Furthermore, our findings remind managers of a new approach to improve return from environmental innovation investment.
\end{abstract}

\section{Keywords}

Environmental Innovation, License Effect, Customer-Based Brand Equity, Atypical Marketing Strategy

\section{Introduction}

Environmental innovation refers to "the creation of novel and competitively priced products, processes, systems, services, and procedures designed to satisfy 
human needs and provide a better quality of life for everyone with a wholelife-cycle minimal use of natural resources (materials including energy and surface area) per units output, and a minimal release of toxic substances" [1]. Environmental innovation is a broader variety of notations compared to "environmental technology", "clean technology", and "green innovation" [2]. Environmental innovation is characterized by its market orientation (satisfaction of need or competitive market position) as well as its environmental benefit over its whole life cycle [3]. A central goal of recent research, therefore, has been to examine how environmental innovation produces economic and environmental benefits [4] [5].

Although the strategic aspects of environmental innovation and their impacts on classic organizational outcomes (such as performance) have been widely studied from a resource-based view (RBV) or natural resource-based view (NRBV) [6]-[11], the strategic implications of external evaluations by third parties-consumers, have failed to trigger similar investigations. Unknown, however, is whether environmental innovation will generate returns and therefore remain acceptable for consumers.

Drawing on insights from customer-based brand equity theory and innovation literature, we argue that high level of environmental innovation grants brands the license to employ atypical strategies without the penalty (in the form of impaired brand attitudes). Moreover, the licensing effectiveness of environmental innovation may be contingent on important contextual factors.

The term licensing effect refers to that high level of environmental innovation grants brands the license to employ atypical marketing strategies which deviate from market convention, without the penalty (in the form of impaired brand attitudes). Marketing typicality involves the frequency with which specific marketing strategies are employed collectively by brands in a category [12]. Atypical marketing strategies deviate from market convention which is perceived by consumers to be typically or commonly used by brands in a product or service category [13]. Atypical marketing strategy should generally be viewed by consumers as inappropriate for a brand to use [12], prompting speculation and suspicion about the firm's motivation for employing the strategy. In contrast, we expect that engagement in environmental innovation can mitigate negative conjecture about atypically used marketing strategies. Environmental innovation provides consumers a basis for positively construing a brand's use of an atypical strategy should attenuate the penalty if consumers view this behavior as appropriate within the context of environmental innovation.

By introducing license effect to marketing literature, we bridge the innovation literature and customer-based brand equity theory by examining correlation between brand environmental innovation and customers' brand attitude. Furthermore, extant work highlights several important advantages of firms associated with environmental innovation, but external evaluations by third partiesconsumers have failed to trigger similar investigations. From the insight of customer-based brand equity theory, we explained that customers will grant brand 
with high-level environmental innovation license to employ execute marketplace strategies in ways not available to less environmentally innovative brands.

We explain that a firm's investment on environmental innovation can earn it potential benefits from successful employment of a wider range of strategies than its competitors. Although prior researches have shown environmental innovation can earn customers' preference and thus promotes firms to invest on it [14], we examine whether firms' effort on environmental innovation can leave them additional competitive advantages. With the license to employ atypical strategy without revenge from customers, a brand can successfully adopt a wider range of strategies (including strategies deviate from marketing convention) than its competitor and thus achieve competitive advantages. Therefore, our research contributes to the theory by unveiling previously neglected competitive advantages associated with environmental innovation.

Our research highlights characteristics of brand (i.e., whether it engage in environmental innovation) and marketing strategy typicality (i.e., whether it deviates from marketing convention). These are important for firms and managers to consider in when developing prospective marketing strategies of brands and predict their outputs. Our findings involve direction for managers to successfully utilize atypical strategies. Furthermore, we provide a new approach for managers to assess their environmental innovation success. By examining the license effect of environmental innovation, manager can assess the success of their effort on environmental innovation.

\section{Theoretical Framework and Hypotheses}

\subsection{A Customer-Based Brand Equity Approach to Environmental Innovation}

Compared with conventional innovation, environmental innovation has important externalities [15], uncertainty [16] and whole-life-cycle characteristic [1]. Environmental innovation concerns the invention of new designs and the creation of novel products and processes to improve resource productivity or reduce environmental impact [1]. It can lead to a cleaner and safer world [15]. Moreover, environmental innovation tends to be more uncertain because there are virtually no standards with respect to specific technologies, which surely makes the production process become more environmental-friendly [16]. Finally, environmental innovation emphasizes the perspective of the whole-life-cycle of the product or a service ("from cradle to grave"), including material extraction, manufacturing (both in relations to the components and final product), distribution, use, reuse and as well as disposal [1].

The above three characteristics may result in perceived excessive economic risks and high costs of environmental innovation activity, which seem major barriers to introduction and market penetration of environmental innovation [1]. Given the high costs and risks, firms constantly seek ways to maximize return on investment in this area. Meanwhile, scholars tend to investigate how en- 
vironmental innovation may benefit firms. Extant literatures focus on impacts of environmental innovation on classic organizational outcomes, such as performance, from RBV or NRBV view (e.g., [6]-[11]). Few literatures highlight effects on external evaluations by third parties (e.g., [17]). In this article, we adopt the latter, external evaluations by consumers, from customer-based brand equity (CBE) perspective to examine benefits of environmental innovation for two reasons.

From the environmental innovation aspect, a strong consumer evaluation of environmental innovation is a key resource that provides firms with strategic advantages at both the firm and market levels. It argued that if environmental innovation strategies can be interpreted as an attempt to meet stakeholder expectations, then identifying salient stakeholders becomes extremely important step in strategy formation. Consumers are primarily salient stakeholders for firms that affect environmental management practices in addition to government regulation [18]. Furthermore, consumers are especially concerned about private benefits [19], e.g. cost and energy savings through more efficient appliances, improved product quality and durability, better repair, upgrade, and disposal possibilities, as well as reduced health impacts [19] [20]. These consumer benefits help firms to overcome the externality of environmental innovations by shifting some portion of the environmental benefit from the public to the consumers. Based on these benefits, consumers evaluate the firm's underlying but unobserved key characteristics [18], increase the demand for environmentally improved products, and can further motivate the firm to implement those innovations for more products and more market novelties [19]. Thus, consumer evaluation is critical to introduction and market penetration of environmental innovation.

On the other hand, customer-based brand equity (CBE) theory provides an appropriate theoretical basis for discussing the contribution of consumer evaluation to environmental innovation. In particular, the theory sheds light on the relationships among consumer reaction, innovation, and ecological issue which constitute the basis for environmental innovation in a holistic view. First, the CBE theory essentially holds that brand knowledge (e.g., associations of product-related attributes and benefits) will lead to consumer differential response to the marketing strategies of the brand [21]. If the consumers hold some favorable, strong, and unique brand associations in memory, they may more favorably evaluate the marketing of the brand. That is, $\mathrm{CBE}$ focuses on consumers' evaluation of firm activities. Moreover, according to CBE, a brand innovation, such as the inclusion of significant new product attributes, can increase consumer evaluation of an average quality by improving the favorability and strength of associations and clarifying core benefits for the brand [21] [22]. Sriram et al. [23] empirically suggested that significant innovations are particularly useful for attaining drastic improvements in consumer evaluation of brand (in forms of price, sale and revenue premium) over a shorter period. Finally, corporate social responsibility (CSR) association, one type of inferred or secondary association in 
CBE theory, will reveal the relationship between ecological issue and consumer evaluation. CSR association reflects the organization's status and activities with respect to its perceived societal obligations, for example, environmental friendliness [24]. Although CSR associations not directly related to the product or service, consumers may infer more specific attributes and benefits related to the product or service from CSR information [21]. Extant literatures empirically found that positive CSR association can enhance consumer evaluation of the overall firm or product (e.g. [24] [25]).

Taken together, the above analysis suggests important linkages between environmental innovation and CBE. CBE theory provides a new approach to discuss the contribution of consumer evaluation to environmental innovation. As for benefits of environmental innovation based on consumer evaluation, a discussion highlighting licensing effect is considered in detail from the perspective of $\mathrm{CBE}$ in the next section.

\subsection{Licensing Effect of Innovation from Customer-Based Brand Equity Perspective}

From customer-based brand equity perspective, innovation will prompt consumers' differential reactions to the marketing strategies [13] [21]. Differential reactions are determined by comparing consumer response to the marketing of high levels of innovation with the response to the same marketing of low levels of innovation. Consumer reactions to the marketing strategies include consumer perceptions, preferences, and behavior arising from marketing strategies [21], in which brand attitudes are importantly empirical measurement of consumer reactions [13] [14]. Keller [21] argued that high level of innovation has specific implication for the marketing strategies related to the brand. Innovation should have more inelastic responses to price changes. Similarly, innovation should result in a willingness to seek out distribution channels for the new product or service. Finally, high levels of innovation can increase marketing communication effectiveness.

Barone and Jewell [12] [13] presented a theoretical framework designed to examine a benefit associated with innovation or licensing effect, namely, improvements in consumer response to a brand's use of atypical strategies. They argued that innovation and marketing strategy typicality can operate independently such that any brand can use strategies that are either typical or atypical of the category in which it competes. A typical strategy should be viewed by consumers as an appropriate means of marketing products, thereby resulting in favorable attitudes towards the strategy. In contrast, an atypical strategy should lead consumers to perceive it as inappropriate, undermining its impact on the attitudes consumers form in response to the strategy. Thus, brands employing atypical strategies will incur less favorable brand attitudes than those use the same strategy under conditions in which consumers view it as typical.

However, Barone and Jewell argued that innovation can provide brands with 
the license to employ strategies that violate marketing convention without penalty (without impairment in brand attitudes that consumers form in response to the strategy). Innovation can provide consumers with a basis for believing that the brand will result in additional innovative offerings that benefit the market when it violates marketing convention. Consumers will interpret atypical strategies in a more favorable light when they are employed by high level versus low level of innovation. It is this leveraging of consumer beliefs about innovation that affords it innovation license to employ atypical strategies without penalty. Therefore, from customer-based brand equity perspective, high-innovation brands can effectively employ marketing strategies in conditions in which the strategy's use is viewed as atypical. In contrast, low-innovative bands are restricted to employing typical marketing strategy, as the use of atypical tactics imposes a persuasion penalty.

\subsection{Environmental Innovation and Licensing Effects}

We argue that engagement of environmental innovation will generate the licensing effects to employ atypical marketing strategies, which deviate from market convention, without the penalty (in the form of impaired brand attitudes). From CBE perspectives, both brand's environmental innovation activities and consumers play vital roles in generating the licensing effects through product-related attributes, benefits and brand attitude. First, environmental innovation is designed to provide products for consumers with a whole-life-cycle minimal use of natural resources, and a minimal release of toxic substances [1]. Environmental innovation brands afford consumers an environmentally sustainable belief and are likely to continue initiatives to reinforce this image through consistency in introducing environmental innovation products. These behaviors that foster the introduction of environmental innovation products have the potential to improve brand attitude [14]. Furthermore, consumers are becoming more environmentally conscious as the world economy shifts towards an ecological orientation. A majority of people say they prefer environment-friendly products and are willing to sacrifice some economic growth for environmental protection [26]. Thus, environmental innovation activities and eco-friendly consumers are critical for licensing effect.

Second, we examine the licensing effects of environmental innovation by capturing the product-related attributes, benefits and brand attitude. Product-related attributes are defined as the ingredients necessary for performing the product function sought by consumers. They relate to a product's physical composition [21]. Environmental innovation products include environmentfriendly attributes of material reduction and recycling, energy-saving, emissions reducing, and hazardous substance substitutes [27] [28]. For example, Ford Motor Company has recently changed the fabric in its car seats to include at least $25 \%$ recycled yams in most cars and $100 \%$ in its hybrid cars. Display Link, a leading provider of USB graphics technology, recently introduced a family of energy-saving USB monitor chips. Simple Green cleaning products now use 
packaging that contains $25 \%$ postconsumer recycled plastic [29].

Benefits are the personal value consumers attach to the product attributes-that is, what consumers think the product can do for them. Benefits can be further distinguished into three categories: functional benefits, experiential benefits and symbolic benefits [21]. Functional benefits are the more intrinsic advantages of product consumption and usually correspond to the product-related attributes, which often are linked to safety and physiological needs. The functional benefits of environmental innovation for the consumer have different sources, e.g. cost and energy savings through more efficient appliances, improved product quality and durability, better repair, upgrade, and disposal possibilities, as well as reduced health impacts [19]. Furthermore, environmental innovation products also have experiential benefits for the consumer, which satisfy experiential needs such as sensory pleasure, variety, and cognitive stimulation [21]. The eco-friendly function of products may trigger positive emotions and enhance consumers' satisfaction [30]. Finally, symbolic benefits are the more extrinsic advantages of product, and relate to underlying needs for social approval or personal expression and outer-directed self-esteem [21]. Environmental innovation products can satisfy consumers' needs for caring for the environmental consequences and for identifying themselves as "green consumers" [30].

Brand attitudes, which refer to consumers' overall evaluation of a brand, are a function of the attributes and benefits that are salient for the brand [21]. Research within the environmental innovation literature has revealed that the evaluation of environmental innovation brands is influenced by the extent to which eco-friendly benefits come from product-related attributes [29]. Certainly, scholars have also argued that the actual nature of brand attitudes depends on consumers' evaluations of attribute and benefit associations, as well as the particular marketing strategies under consideration [21] [31]. Environmental innovation creates eco-friendly attributes that are material reduction and recycling, energy-saving, emissions reducing, and hazardous substance substitutes [21], which conveys functional benefits of health, cost and energy savings [19], experiential benefits of positive emotions and high consumers' satisfaction [30], and symbolic benefits of care for the environmental consequences and identification of "green consumers" [30]. Attributes and benefits are certain standards that consumers rely on to infer atypical marketing strategies. Consumers may positively infer that atypical strategies deviating from marketing convention reflect brands' efforts to continue to innovate in the market [15]. For example, atypical pricing, high price, consumer will interpret that it implies radical modifications, and be willing to pay premium price. In contrasts, low price, consumers interpret that brands intends to compete on lower prices by completely revisiting the products and even entering new industries [32].

Based on the above discussion, we propose our first hypothesis:

$\mathrm{H}_{1}$ : When an atypical marketing strategy is employed, environmental innovation will provide a licensing effect. 


\subsection{License Effect in Recycle Phase}

Environmental innovation devotes to provide people with products with a lifecycle minimal use of natural resources (materials including energy, and surface area) per unit output, and a minimal release of toxic substances [1]. The term "life-cycle" refers to the assessment of raw material production, manufacture, distribution, use and disposal, including all required transportation steps. Therefore, to measure the environmental impacts of a product for its entire life-cycle and reduce its impact on environment, instruments, such as life-cycle analysis, were adopted in many countries [33].

Disposal is one of the important phases that have serious impact of products' life-cycle on environment. For one thing, it is estimated that 80 per cent of the products we buy today become waste within one year of purchase [33]. For another, waste products are considered a vital source what seriously pollute the environment and endangers human health [34]. Thus the disposal progress has serious impact on products' life-cycle impact on environment. Moreover, the left value of used products is often neglected [35]. Therefore, disposal of waste and used products has become a problem for governments and firms [35] [36].

Firms find out that the recycling, one of the disposal ways, offers considerable environmental advantage compared to other disposal options like landfill and incineration, and recovers substantial financial value reducing manipulation cost [34] [35]. In order to reduce the negative effect of the waste of used products and recovery their left value, recycling strategies have be adopted by many companies [36] [37] [38]. For example, with rapid global advancement and an exponential growth rate in the electrical and electronic industries in the 21st century, there has come a corresponding change in consumer lifestyles, resulting in the generation of a huge amount of end-of-life electronics, known as electronic waste (e-waste) [39]. China has made an enormous contribution to global e-waste production: in 2014, the amount of globale-waste hit record highs of 41.8 million tons and China ranked second in the world with six million tons of e-waste discarded [40]. The used electronics contain significant amounts of hazardous materials which will pollute the environment and affect our health, such as mercury, lead, cadmium, and polychlorinated biphenyls. On the other hand, used electronics contain high-value materials such as gold, palladium, copper, and plastics. They also have potential negative environmental impacts [39] and recovery of precious mental is considered as the major economic driver for recycling electronic waste [41]. Furthermore, several obsolete electronic devices, which are clean and functional, can be reused if identified and sorted out by experts.

Accordingly, recycling strategy was adopted by firms to reduce manufacture cost and reduce their impact on the environment creating public interest. China has 105 enterprises dismantling e-waste at fixed-point places, about $50 \%$ of waste electrical and electronic products flow to normal channels for processing [40]. However, recycling brings customers more public benefit than personal 
benefit. For one thing, the environmental benefits it brings are hard to comprehend, involve uncertainty, and require delayed gratification [19]. For another, customers concern more about their personal benefit than public interest, many consumers are even reluctant to pay premium prices or trade off other product qualities solely for a product's green attributes [42], so neither will them sacrifice their personal benefit for public interest recycling brings. It was also found that consumers with a lower level of environmental affect responded better to green appeals that focused on personal benefits rather than pure environmental appeals [43]. Therefore, in recycling strategy condition, customers construe the adoption of atypical strategy by a high level of environmental innovation brand as a behavior that will only benefit the public and reduce manipulation cost, thus atypical strategy may cause negative impact on customers' brand attitude no matter the level of the brand's environmental innovation is high or not. That is to say, high level of environmental innovation cannot offer a brand with license effect in recycling strategy condition.

$\mathrm{H}_{2}$ : The licensing effect of environmental innovation will disappear when an atypical marketing strategy is employed in recycle phase.

\section{Overview Study}

To verify our hypotheses, we conduct three studies that varies environmental innovation at the attribute (Study 1) and brand level (Study 2 and 3), that examine license effect for pricing (Study 1,2) and recycling (Study 3). We verified the existence of license effect at attribute level in Study 1 and brand level in Study 2 to verify $\mathrm{H}_{1}$. Study 1 illustrates that a brand producing product with high level of attribute-basic environmental innovation can effectively employ pricing strategies that violate marketing convention without penalty. Corresponding, a brand producing product with low-level innovation may suffer from penalty owing to the employment of atypical strategies. These results support the license effect posited in $\mathrm{H}_{1}$. Study 2 extended initial study by demonstrating license effect using fictional brands varying in their environmental innovation.

We further investigated the applicable scenarios of license effect by testing its existence in recycling strategy in Study 3. The third study illustrates license effect may disappear in some case, citing that license effect will disappear when atypical marketing strategy is used in recycling phase.

\subsection{Study One}

Environmental innovation creates eco-friendly attributes [27], which conveys functional benefits [19], experiential benefits, and symbolic benefits [30]. The standards that consumers rely on to infer atypical marketing strategies are attributes of environmental innovation and the benefits products bring. Consumers may positively construe atypical strategies deviating from marketing convention as brands' efforts to continue to innovate in the market [13]. By offering products with the attribute of high level environmental innovation, a 
brand can be endowed with the license to employ atypical strategy without penalty.

We assumed that a brand offering products with more environmental innovation is more likely to develop reputation for being green, innovative and responsible. Consumes may endow the brand with license to employ atypical strategy without penalty. In this study, we were going to verify that, given a brand producing products with low level of environmental innovation, consumes should not grant it the latitude to employ atypical strategy without penalty, while brand with high level of environmental innovation could effectively employ atypical strategy owing to the license effect $\left(\right.$ see $\left.\mathrm{H}_{1}\right)$.

\subsubsection{Design and Method}

One hundred and three students were assigned randomly to the cell of a 2 (attribute environmental innovation: more innovative vs. less innovative) $\times 2$ (strategy typicality: typical vs. atypical) between subjects design. After some initial instructions, firstly, participants received the environmental innovation manipulation and the typicality manipulation. Then they were asked to respond to manipulation check questions to assess the success of manipulations and an item that measures relative brand attitude. After the experiment, each participates would get $15 \mathrm{RMB}$ in return.

Prior research (e.g., [44]) has demonstrated the importance of the standards consumers possess in their evaluation of a company's pricing strategy by showing, for example, unfavorable reactions to price increases that deviate from marketing convention. Thus, strategy of increasing price that violates marketing convention is considered atypical strategy that commonly unappreciated by customers. We manipulation strategy typicality by altering participates' perception of brands' pricing strategy.

\subsubsection{Procedure}

At first, participants processed information of a fictional brand aimed at creating differences in the levels of the attribute environmental innovation and the extent to which the employment of pricing strategy was perceived as complying with marketing convention for water heater. In order to avoid relying on participants' a priori views of an existing brand's innovativeness, we adopted a fictional consumer electronics brand, Consul.

For the manipulation of strategy typicality, this manipulation established baselines about pricing strategy typicality by presenting results from what was a survey of pricing strategy of water heater. In the typical condition, a fictional brand carried out the pricing strategy (high-priced strategy) that $85 \%$ of its competitors employed. In the atypical condition, a fictional brand adopted the pricing strategy (high-priced strategy) as $20 \%$ of its competitors' adoption.

For the manipulation of the level of attribute-basic environmental innovation of products, in the high innovation condition, a fictional brand offered a new kind of air-source water heater with technology saving $75 \%$ electric energy con- 
sumption and $400 \%$ increased heating efficiency compared with common water heater. In the low innovation condition, a fictional brand produced gas water heater with technology saving 50\% electric energy consumption and $250 \%$ increased heating efficiency compared with common water heater. Besides, reading passages also include competitive products and their attributes in both conditions.

Following the manipulations, to identify these manipulations, participants were asked to respond to one manipulation check question of the level of environmental innovation ( $1=$ the lowest level of environmental innovation; $9=$ the highest level of environmental innovation) and five manipulation check questions of strategy typicality ( $1=$ most atypical; $9=$ most typical). Finally, we use one question with the nine-point Likert scale to measure the brand attitude of the fictional brand ( 1 = "not favorable" or "negative", 9 = "favorable" or "positive").

\subsubsection{Result}

We first developed two perceived innovative scores by participants' response on the questions that checked the manipulation of the level of environmental innovation and strategy typicality. Validating our manipulation, an ANOVA revealed a main effect of perceived attribute innovation: Participants who read the essay that tells a brand with less attribute-based environmental innovation perceived the attribute less innovative $\left(M_{1}=4.04\right)$ than those who read the essay that tells a brand with more attribute-based innovation $\left(\mathrm{M}_{2}=6.98, \mathrm{~F}(1,101)=150.69, p<\right.$ 0.001).

We took an average of the five manipulation check questions for strategy typicality to form a manipulation check score. An ANOVA indicated a main effect of strategy typicality: Participants indicated a main effect of perceived strategy: Participants who received the message telling a typical strategy employed by a brand perceived the nature of strategy more typical $\left(M_{1}=7.06\right)$ than those who received the message telling an atypical strategy employed by a brand $\left(\mathrm{M}_{2}=4.00\right.$, $\mathrm{F}(1,101)=329.92, p<0.001)$.

Our framework predicts that a brand with high level of environmental innovation should engage the license to employ atypical strategy without penalty. According to our framework, brands may effectively employ atypical strategy when the attribute of a brand is more environmentally innovative. Conversely, because brands using atypical strategy to sell products with less-innovative attribute are unlikely to be accepted by customers, they should be subject to a penalty for employing atypical strategy.

Consistent with $\mathrm{H}_{1}$, significant effect to emerge from a $2 \times 2$ ANOVA on brand attitudes involves the strategy typicality $\times$ attribute environmental innovation interaction $(\mathrm{F}(1,99)=5.57, p<0.05)$. Simple effects tests revealed that, when the nature of attribute was more environmentally innovative, brand attitude were unaffected by marketing convention $\left(\mathrm{M}_{\text {typical }}=6.53, \mathrm{M}_{\text {atypical }}=6.25\right.$; $\mathrm{F}(1,99)=0.53, p>0.05)$. On the other hand, the less-innovative attribute en- 
gendered more favorable attitude $(\mathrm{F}(1,99)=15.65, p<0.001)$ when participants viewed strategy as typical $\left(M_{\text {typical }}=5.93\right)$ rather than atypical $\left(M_{\text {atypical }}=3.30\right)$ of strategy typicality. As such, these results reflect the license effect of high level of environmentally attribute-basic innovation on brand attitude, which is posited in $\mathrm{H}_{1}$ (see Figure 1). It means that a brand with high level of attribute environmental innovation can carry out atypical strategy such as high price strategy, consumer will interpret that it implies radical modifications, and be willing to pay premium price. While it is unreasonable that a brand without attribute environmental innovation may suffer from penalty when adopting atypical strate-

gy.

\subsubsection{Discussion}

In Study 1, a fictional brand offering products with high-level environmental innovation contributed to participants perceiving the brand as more environmentally innovative. Corresponding, offering products with low-level environmental innovation, the fictional brand was perceived as less environmentally innovative. According to our theorizing, a brand perceived as more environmentally innovative can effectively employ atypical strategy without penalty owing to license effect. Thus, offering products with high-level environmental innovation can make the brand perceived more environmentally innovative and granted the license to employ atypical strategy without penalty.

The results in Study 1 illustrate that offering products with high level of environmental innovation can bring about license effect in an attribute-basic environmental innovation, which is not sufficient to produce the theorized license

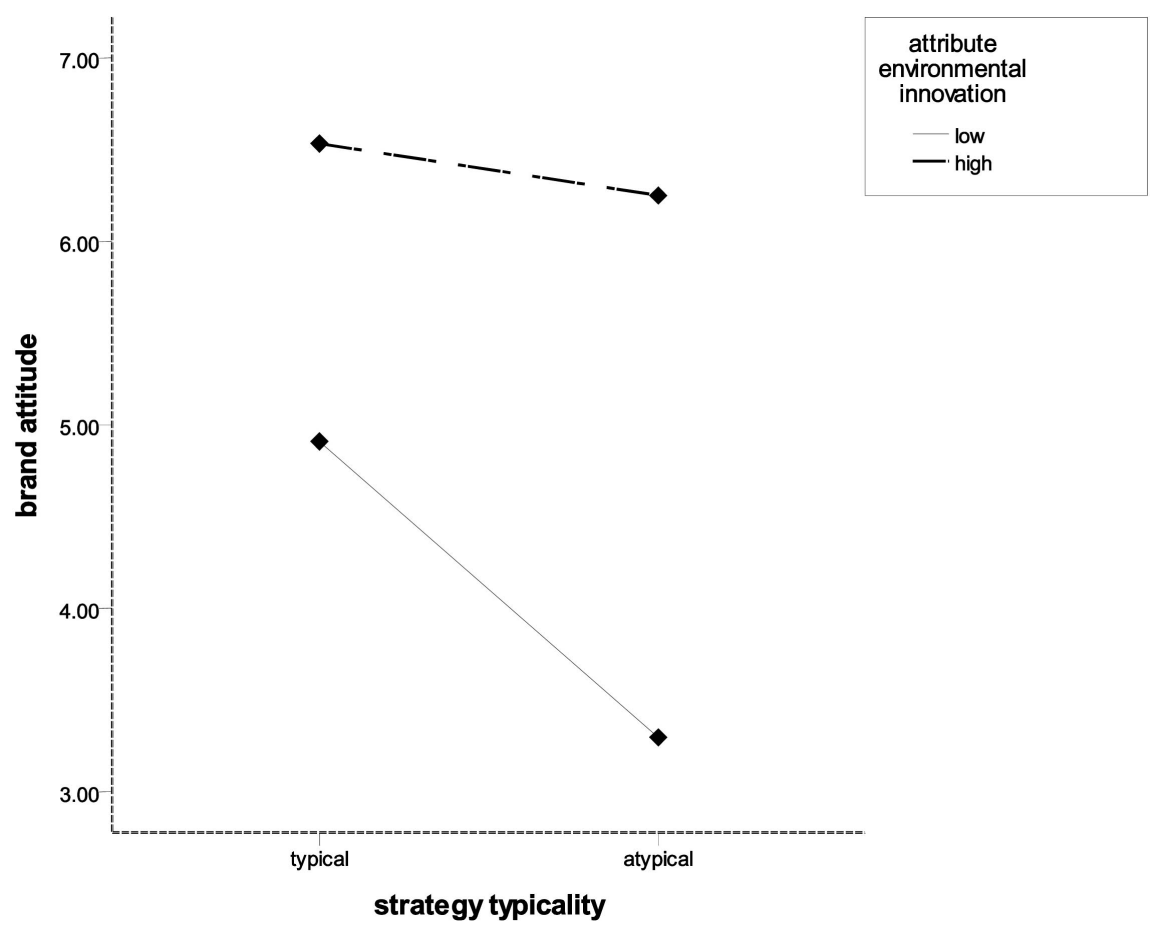

Figure 1. License effect in attribute-basic condition. 
effect of a brand, as the license effect was derived from the attribute of new products not the environmental innovation of the brand. Study 2 examines whether the effects found in Study 1 with respect to attribute-based environmental innovation are robust enough to materialize with respect to brand-level innovation.

\subsection{Study Two}

\subsubsection{Method and Design}

One hundred and seventy-eight students were assigned randomly to one of the cells of 2 (brand environmental innovation: more innovative vs. less innovative) $\times 2$ (strategy typicality: typical vs. atypical) between subject design. Participants were first asked to read manipulation passages to create differences in the extent to which the employment of pricing strategy was perceived as complying with marketing convention for water heater, which mirrored that used in Study 1, and in the levels of environmental innovation of a fictional brand. The manipulation of environmental innovation in brand level in this study was different from that in attribute level in study 1 . To make participants perceived the brand with different levels of environmental innovation, participants received passages presenting a brand with an introduction of either high or low level of environmental innovation.

They subsequently responded to manipulation check questions. The manipulation check of strategy typicality was the same as that in Study 1. For the manipulation check of the level of brand environmental innovation, students were asked to complete seven manipulation check questions. Finally, two questions with nine-point Likert scales were collected to examine potential alternative accounts for the strategy typicality $\times$ brand innovativeness interaction predicted for brand attitudes, which also mirrored that used in Study 1. After participants completed this experiment individually and each of them would receive $20 \mathrm{RMB}$ reward for their participation.

\subsubsection{Procedure}

Firstly, participates were asked to read the passages introducing a fictional brand that created the difference in level of the brand environmental innovation and strategy typicality of the pricing strategy it employed. The manipulation of strategy typicality in this study is mirrored that in study 1 . Whereas the manipulation of environmental innovation in this study was basic on the brand level, it was basic on the products' attribute level in Study 1.

For the manipulation of brand environmental innovation, in order to avoid relying on participants' a priori views of an existing brand's innovativeness, we adopted a fictitious consumer electronics brand, Consul, for manipulating the perceptions, as being either more innovative brand or not. All participants were told that Consul ran in a few China cities but would soon be selling products nationally. We developed two brand descriptions to lead to the result that the brand's innovativeness was considered as low and high respectively. In the 
high-level environmental innovation condition, Consul was described as the leader of the new era for energy-saving and it was the first company that launches energy-saving water heater for the market. Then some description of its contribution to social environment and the water heater industry and prizes it had got followed. In the low-level environmental innovation condition, Consul was described as a brand that followed the new era for energy-saving in order to gain market share. Then some description of its small contribution to the social environment was followed.

Subsequently, participates completed the manipulation check questions of brand environmental innovation and strategy typicality. The questions for strategy were the same as those in the Study 1 . Whereas the manipulation check questions for brand environmental innovation differed from that in Study 1. In this study, seven manipulation check questions of brand environmental innovation were divided into two parts. The higher scores in the first four questions meant that the brand engaged more innovation; corresponding, the higher scores in the latter three questions meant that the brand was less innovative. Then they were averaged to develop manipulation check score of the brand environmental innovation respectively.

Finally, two questions with 9-points Liket scales for the brand attitude were used to measure the brand attitude of Consul, which was also mirrored Study 1.

\subsubsection{Result}

Participates' responses to the seven manipulation check questions for environmentally innovative level were divided into two parts. The first form a manipulation check score perceiving for the level of brand innovation by participates' responds to the four manipulation check questions. They were averaged to form a manipulation check score. As expected, participates who received the message with a high innovative brand perceived the brand high innovative $\left(M_{1}=5.16, M_{2}\right.$ $=6.76, \mathrm{~F}(1,176)=55.15, p<0.001)$. The second form a manipulation check score perceiving for the level of brand environmental innovation with three manipulation check questions. The higher score the brand got meant that the lower level of brand innovation the brand had. The responds to the three questions were averaged to form the manipulation check score. Participates who received the message informing a high innovative brand also perceived the brand more innovative $\left(\mathrm{M}_{1}=5.24, \mathrm{M}_{2}=3.08, \mathrm{~F}(1,176)=95.14, p<0.001\right)$, confirming the success of the manipulation of the level of brand innovation.

Besides, we developed a manipulating check score perceiving for strategy typicality through five manipulation check questions. They were averaged to form a manipulation check score. Participates who received the information telling a brand adopting typical strategy perceived the strategy more typical $\left(\mathrm{M}_{1}=7.25\right.$, $\left.\mathrm{M}_{2}=4.25, \mathrm{~F}(1,176)=299.88, p<0.001\right)$, affirming the success of the manipulation of strategy typicality.

Our framework predicts that a brand with high level of environmental innovation should engage the license to employ atypical strategy without penalty. A 
brand with high level of environmental innovation can effectively adopt atypical strategy while the brand with less environmental innovation may suffer from penalty owing to the employment of atypical strategy.

Squaring with $\mathrm{H}_{2}$, significant effect of the strategy typicality $\times$ brand environmental innovativeness interaction $(\mathrm{F}(1,174)=6.97, p<0.01)$ emerged from a $2 \times$ 2 ANOVA on brand attitudes. Simple effects tests illustrate that when the nature of brand was more environmentally innovative, brand attitude were unaffected by marketing convention $\left(\mathrm{M}_{\text {typical }}=6.43, \mathrm{M}_{\text {atypical }}=6.60, \mathrm{~F}(1,115)=0.36, p>\right.$ 0.05). Corresponding, the less environmentally innovative brand engendered more favorable attitude $(\mathrm{F}(1,174)=9.72, p<0.01)$ when participants viewed strategy as typical $\left(\mathrm{M}_{\text {typical }}=5.76\right)$ rather than atypical $\left(\mathrm{M}_{\text {atypical }}=4.88\right)$ of strategy typicality. As such, these results reflect the license effect of high level of environmental brand innovation on brand attitudes, which is posited in $\mathrm{H}_{1}$ (see Figure 2).

\subsubsection{Discussion}

Study 2 confirmed that a brand with high level of brand environmental innovation can be granted with license to employ strategy that violates marketing convention without penalty. Demonstrating the robustness of the license effect, Study 2 provides evidence of this interaction based on a brand's overall reputation for being environmentally innovative that parallels the results found in Study 1 with respect to credit and licensing effects arising at the attribute level.

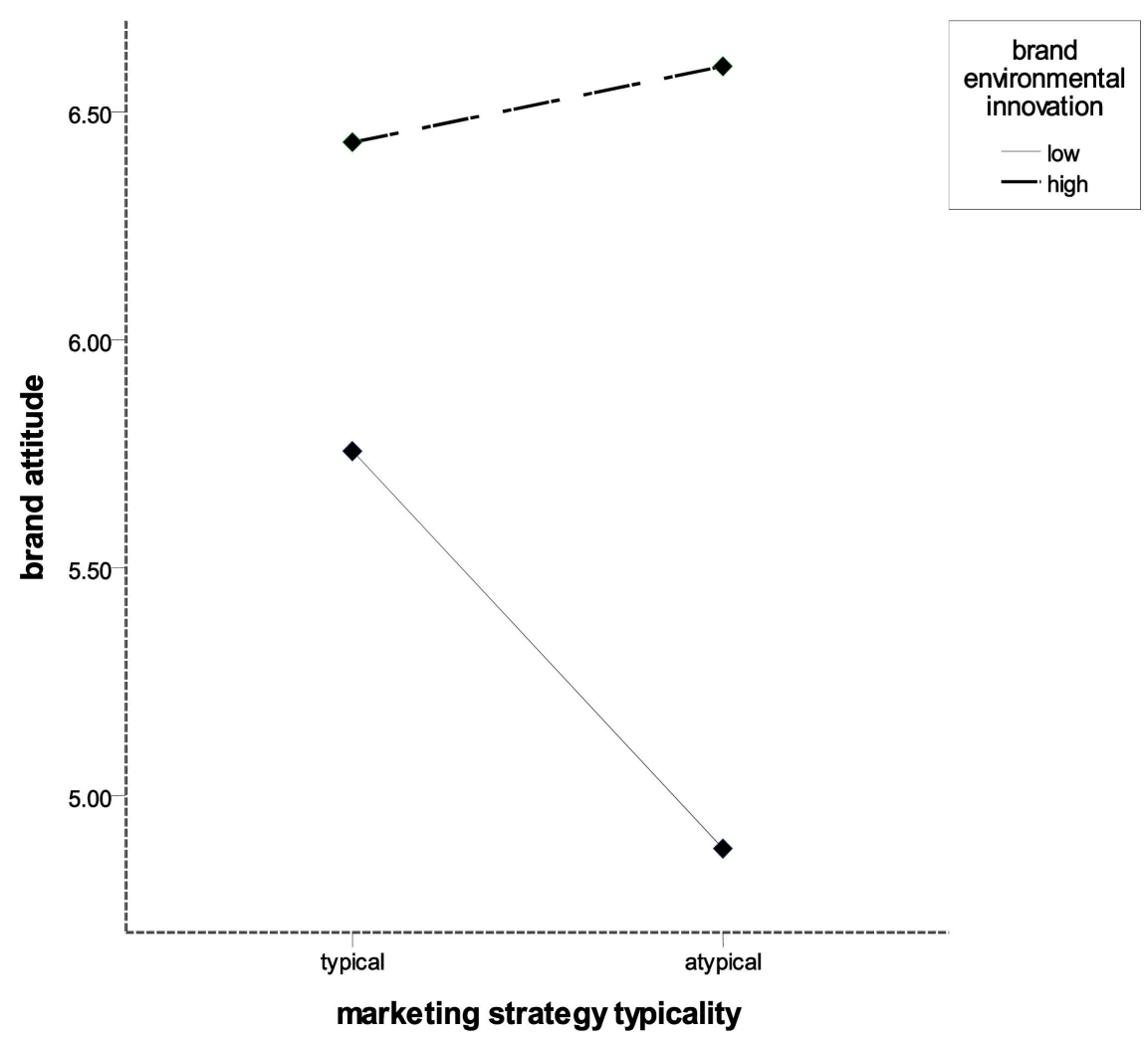

Figure 2. License effect in brand-level condition. 
Study 1 and Study 2 had already confirmed the license effect of attribute-basic environmental innovation and brand environmental innovation. To test whether the license effect can be influenced by some important factors, Study 4 focused on whether license effect can work on recycling strategy.

\subsection{Study 3}

According to study 1 and 2, the results of pricing strategy had been proved to be influenced by license effect. In study 3 , we would take recycling strategy into consideration. The license effect on recycling strategy will be tested in this study.

\subsubsection{Design and Method}

One hundred and seventy-eight students were assigned randomly to the cell of 2 (brand environmental innovation: more innovative vs. less innovative) $\times 2$ (strategy typicality: typical vs. atypical) between subjects design. Firstly, participates would process the manipulation of the level of environmental innovation, which was the same as study 2 . And then the manipulation of strategy typicality followed. In the manipulation of strategy typicality, compared with study 2 , we would consider recycling strategy instead of pricing strategy. Besides, the manipulation check and the measurement of brand attitude were all the same as study 2.

In the recycling progress, the collection phase plays a key role between customers and firms. Although recycling can reduce used products' negative impact on the environmental and benefit manufacturers, for the used products are collected from end-customers, the return rate of used products relies on the end-customers' willingness and attitude which are affected by the collection price [45]. On one hand, the return rate of used products is affected by collection price. On the other hand, for the price of a recycled material is affected by the amount of the recycled material. Thus firms' financial benefit from the adoption of recycling and customers' attitude towards recycling, finally towards the brand which adopts recycling strategy, are affected by the decision of collection price [46]. Therefore, we test whether brands' employment of atypical recycling strategy will suffer from penalty on high or low level of environmental innovation condition by manipulating brands' decision of collection prize in Study 3.

\subsubsection{Procedure}

After some initial introduction, participates were asked to read the information telling a fictional brand, Consul, with either high or low level of brand environmental innovation employ either typical or atypical recycling strategy. The manipulation information of brand environmental innovation was the same as that in Study 2, whereas the manipulation of strategy typicality in this study was different from that in Study 2.

For the manipulation of recycling strategy, participates were asked to read the information different from study 2 . In the typical condition, the fictional brand employed the recycling strategy which was employed by $80 \%$ of its competitors. 
While in the atypical condition, the fictional brand employed the recycling strategy which was only employed by $20 \%$ of its competitors.

The later manipulation check and the measurement of brand attitude were the same as those in Study 2.

\subsubsection{Result}

The manipulation check questions of environmental innovation were also divided into two parts as Study 2 did. Participates who received the information of more innovative brand perceived the brand more innovative $\left(M_{1}=6.84\right)$ than those who received the information of less innovative brand $\left(\mathrm{M}_{2}=5.03, \mathrm{~F}(1,176)\right.$ $=147.18, p<0.001)$ in the first part of questions. Participates who were received the message with a more innovative brand perceived the brand more innovative $\left(\mathrm{M}_{1}=5.29, \mathrm{M}_{2}=2.88, \mathrm{~F}(1,176)=135.82, p<0.001\right)$ in the second part. These confirmed the success of the manipulation of the level of environmental innovation.

The result of the manipulation check questions of strategy typicality also confirmed the success of the manipulation. Participates who received the information telling a brand adopting typical recycling strategy perceived the strategy more typical $\left(\mathrm{M}_{1}=6.98\right.$ vs. $\left.\mathrm{M}_{2}=3.95 ; \mathrm{F}(1,176)=279.33, p<0.001\right)$.

We argue that license effect will not impact on recycling strategy. It means that when employing atypical strategy, a brand with high level of environmental innovative will been punished as well as a brand with low level of environmental innovation.

Squaring with $\mathrm{H}_{3}$, significant effect of strategy typicality $\left(\mathrm{M}_{1}=6.20, \mathrm{M}_{2}=5.05\right.$; $\mathrm{F}(1,174)=5.97, p<0.05)$ emerged from a $2 \times 2$ ANOVA on brand attitudes and the effect of the strategy typicality $\times$ brand environmental innovativeness interaction was not significant $(\mathrm{F}(1,174)=0.10, p>0.1)$, which was affirming that the licensing effect of environmental innovation will disappear when an atypical marketing strategy is employed in recycle phase. That is to say, when an atypical strategy of recycling was employed, firms with high level of environmental innovation or not will suffer from penalty. When in low level of environmental condition, the employment of typicality recycling strategy could engage the brand with more favorable brand attitude $\left(\mathrm{M}_{1}=5.91, \mathrm{M}_{2}=4.82, \mathrm{~F}(1,174)=\right.$ 13.13, $p<0.001)$. When in high level of environmental condition, the fictional brand also suffered from penalty when adopting atypical recycling strategy $\left(\mathrm{M}_{1}\right.$ $\left.=6.50, \mathrm{M}_{2}=5.28, \mathrm{~F}(1,174)=16.17, p<0.001\right)($ see Figure 3$)$.

\subsubsection{Discussion}

Although recycling strategy can effectively reduce the impact of production on environment [34], atypical strategy of recycling was found not acceptable to be employed by firms with high level of environmental innovation in this study. At first, recycling is considered contribute to the public interest and reduction of manipulation cost [40] [41] more than personal benefit, atypical recycling strategy is construed as behavior that sacrifices personal benefit for public and firms' 


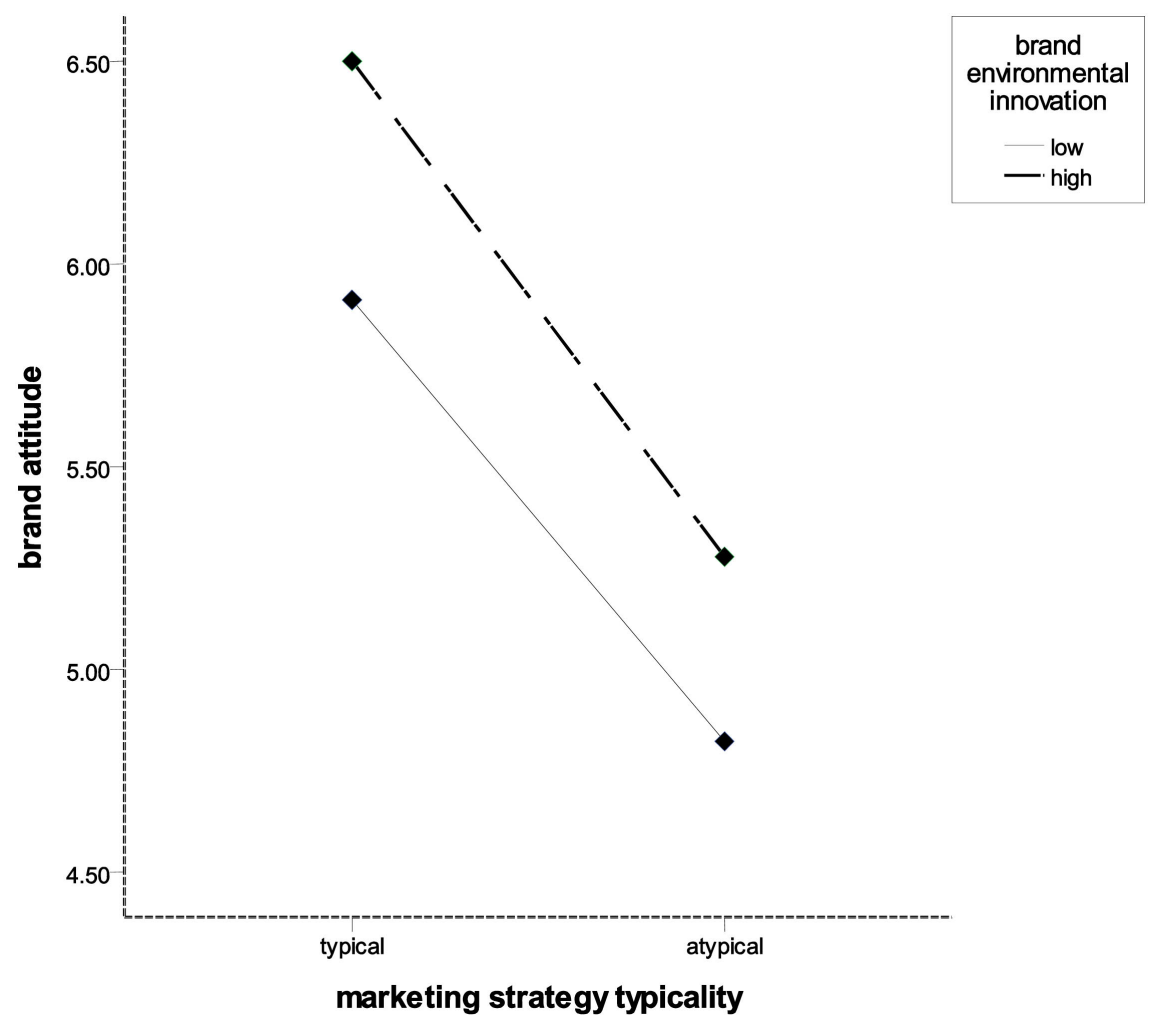

Figure 3. License effect in recycling strategy condition.

interest. Furthermore, customers concern more about personal benefit than public interest [19] [42]. Thus atypical recycling strategy is unappreciated by customers. Corresponding, typical recycling strategy can bring about more favorable brand attitude when firms are in either low or high level of environmental innovation condition. Brands with high level of environmental innovation are not granted with competitive advantages by employing atypical recycling strategy. Therefore, license effect takes no effect when brands carry in some sorts of strategies. Further discussion was needed to find out whether license effect can take into effect on other sorts of strategy.

\section{General Discussion}

To find out how brand's violating marketing convention influence consumers' brand attitude, we used findings from customer-basic brand value perception to introduce the concepts of license effect to explain our discovery. Examining this concept highlights an important benefit of environmental innovation that managers may not fully appreciate. Specifically, our results suggest that a brand's contribution to environmental innovation can enable it to effectively employ strategies that deviate from market convention and thus obtain competitive advantage and generate return.

\subsection{Theoretical Contributions}

This research makes several contributions to the current literature. First, we 
bridge the innovation literature and customer-based brand equity theory by examining correlation between brand environmental innovation and customers' brand attitude. Historically, the strategic aspects of environmental innovation and their impacts on classic organizational outcomes (such as performance) have contributed to the implications from a RBV or NRBV [6]-[11], yet the current findings shed light on a previously unexplored benefit whereby its contribution to brand value. From the insight of customer-based brand equity theory, we verifies that environmental innovation will have specific effect on customers' reaction to brands' marketing strategies and finally generate returns.

Second, extant work highlights several important advantages of firms associated with environmental innovation, but external evaluations by third parties-consumers have failed to trigger similar investigations. Drawing on insight of customer-based brand equity theory, our study found out that environmental innovation grants brand with license to adopt atypical strategy without penalty, customers' evaluation (in the form of brand attitude) of brand with high level of environmental innovation will not be damaged by the employment of atypical strategy. Thus, customers' highly praise of products with environmental innovation will increase the demand for environmentally improved products, and can further motivate the firm to implement those innovations for more products and more market novelties [19].

Third, prior researches have not focused on the interaction between environmental innovation and marketing strategy to explain the adoption of environmental innovation strategies [14]. We explain the relationship between them with license effect. Evidence offered regarding the licensing effects examined here is relatively novel to the innovation literature. With high level of environmental innovation, brands were granted the ability to employ strategy deviate from marketing convention without penalty. Thus, they had the advantage to execute marketplace strategies in ways not available to less environmentally innovative brands.

Furthermore, because the license effect is rooted in customers' inferring of brand's atypical strategy. Those strategies that customers construe as behaviors which are no good for or even damage their interest are unappreciated and repulsed by customers. The result in Study 3 illustrated that atypical recycling strategy was construed as brand's behavior that only benefit firms and public and thus is unacceptable by customers. Under such conditions, consumers may respond unfavorably to a strategy deviate from marketing convention employed by an environmentally innovative brand, license effect disappears owing to customers' inferring no personal benefit from the employment of atypical strategy.

Finally, our findings are particularly important because they accommodate a broader articulation of the potential benefits associated with environmental innovation. As the license effects illustrated here, a brand's investment in environmental innovation may have rather fundamental implications regarding its ability to effectively adopt a wider range of strategies than the brand's competitors, including the employment of approaches unconventionally employed in the 
marketing in which it competes. Compared with results demonstrating a penalty for brands without environmental innovation that use atypical strategies, license effect can preserve and enhance the competitive advantages environmental innovators enjoy.

\subsection{Managerial Implications}

As current marketplace reveals a mounting emphasis on environmental sustainability [14], firms increasingly seek ways to maximize return on investment of environmental innovation. While the impacts of environmental innovation on classic organizational outcomes, such as performance, have been widely study. Our research concentrated on the strategy advantages of firms investing on environmental innovation derived from customers' evaluation. By illuminating the license effect with respect to consumers' evaluations of a brand's marketing strategies, our results provide a rationale for managers to adopt in selling their products. Specifically, these findings offer a novel approach in evaluating the success of a firm's environmental innovation efforts that involves an environmentally innovative brand's ability to successfully employ a wider range of strategies than the brand's competitors.

Our research offers direction for manager who oversees a firm's environmental innovation efforts in particular and, more generally, the development of its marketing strategy. Managers may simply concern about whether a brand's strategy conforms to marketing convention. Managers may avoid penalty by adopting conventional marketing strategy only. However, the results of our first two studies presented here show that the usage of unconventional marketing approaches does not always lead to poor outcomes. When customers consider a strategy's conformity to marketing convention into their evaluations (see the results germane to $\mathrm{H}_{1}$ ), a brand's specific characteristics and past behavior will leave important impact on acceptability of unconventional marketing strategy. These findings further implicate that predicting the success of a marketing strategy requires not only an understanding of the marketing convention in which a brand competes but also of certain key characteristics associated with the brand (i.e., if customers perceive it environmentally innovative).

Thus, our findings highlight the importance of understanding that the environmentally innovative image of a brand is treated as part of its customer-based brand equity and leads to license effect. Such equity can serve as a vital asset that grants this brand to utilize unconventional strategies without fear of reprisal from customers. On the contrary, if the brand with a lack in environmental innovation adopts the same approach, it will yield seriously punitive results. Indeed, our findings paint a rather dismal picture for brands lack of environmental innovation, given that a lack of past environmental innovation precludes their ability to innovate through the use of novel strategies, placing them at a further disadvantage compared with more environmentally innovative brands.

The implication of these findings for managers is noteworthy. Environmental innovation can provide brands with a license to employ a relatively wide range 
of strategies (including those deviating from marketing convention), whereas competitors suffer from reprisal from customers once adopting atypical strategy. Managers can also evaluating the success of a firm's investment on environmental innovation by examining brands' license effect. Successful employment of environmental innovation strategy will lead to license effect and thus leave brands to benefit from competitive advantage of adopting a wider range of strategy.

Considered with great benefit from investment on environmental innovation, managers will increasing emphasize on it. By offering products with high level environmental innovation, brands can obtain brand equity of being green and economic benefits, and in this manner, complementary coexistence and common prosperity can be achieved between environmental protection and firms' economic benefits. Benefits obtained through environmental innovation will motivate brands to commitment to environmental innovation which are capable of increasing the efficiency of resource use, thereby attaining the ideal in terms of protecting the Earth's ecology and maintaining sustainable economic development.

However, successful achievement of competitive advantage through environmental innovation requires adequate understanding of license effect. License effect does not always work in specific strategy, including recycling strategy we tested in Study 3. In some area of strategy, customers construe these strategy deviate from marketing convention as behavior sacrificing their personal benefit for other stakeholders' interest (like firms' and public interest in recycling strategy condition). License effect works because customers infer that environmentally innovative brands' atypical strategies serve their personal benefit including functional benefits, experiential benefits and symbolic benefits. Therefore, before adopting an atypical strategy, managers are supposed to speculate and examine customers' potential idea inferred from this atypical strategy. Though with environmental innovation, a brand will be punished by customers for employing atypical strategy leaving without personal benefit perceived by them. Only these atypical strategies which customers construe as behaviors that benefit them can customers appreciate for and can managers employ to achieve competitive advantage through environmental innovation's license effect.

In conclusion, our study offers direction for manager to achieve return from investment on environmental from adopting some atypical strategy under the protection of license effect, such as high pricing strategy. In this way, atypical strategy can be relative to higher product performance. However, license effect disappears when customers construe these strategies deviate from marketing convention as behavior sacrificing their personal benefit for other stakeholders' interest. For example, recycling strategy is always reminiscent of protecting the environment, but not the performance of products. Firms are thought to sacrifice customers' personal benefit for pulic interest when firms carry out atypical recycling strategy. Thus, brand with high level environmental innovation also suffer from penalty when employing atypical recycling strategy. 


\subsection{Limitations and Further Research}

In our research of license effect of environmentally innovative brand, we centered on brand attitude. Whereas we illustrate important implications with regard to how environmental innovation provide license effect on customers' brand attitude, further research could investigate other brand-level effects, such as brand equity or sales.

Furthermore, license effect is relatively novel to marketing literature. Further inquiry into whether employment of unconventional strategy will reduce or generate additional license effect in a long-term effect would be useful in gaining a deeper understanding of license effect. For example, adopting strategy deviate from marketing convention can have inconclusive result. On one hand, it increase the risk of purchase, thus it can be treated as behavior that consume customers' trust and customer-basic brand equity. License effect will finally fall off in the long-term. On the other hand, atypical strategy can be considered as innovative behavior. We wonder if atypical strategy would be accepted as part of environmental innovation and strengthen the brand's image of being green. Consequently, atypical strategy will strengthen license effect in the long-term. Given all that, deeper understanding of license effect requires further inquiry into it in a long-term.

Moreover, we acknowledge that some factors may also influence license effect. For example, the perceived credibility of brands' environmental innovation may moderate the license effect on customers' evaluation of atypical strategy. The more credibility a brand perceived as being environmentally innovative, the more customers trust in the brand to contribute to their benefit. Thus environmental innovation grants a brand with more perceived credibility of being environmentally innovative more license effect. Besides, the environmental awareness of customers and product type may also influence license effect.

Finally, our study tested license effect on pricing and recycling strategy. Further examinations of other strategies are needed to contribute to the identification of its boundary. Besides, we test license effect only in the China. Some developed countries, especially in Europe, have a longer history of environmental concern. The environmental awareness and behaviors of customers in these countries are different from these in China. Therefore, further research could expand the generalizability of our results to other countries where rules and regulations regarding environmental sustainability may offer additional insight into license effect.

\section{Conclusion}

This research is to explain an unexplored benefit associated with brands' environmental innovation, license effect that a brand's contribution to environmental innovation can enable to effectively employ strategies which deviate from market convention and thus obtain competitive advantage and generate return. We finally confirmed the existence and discussed the applicable scene of license 
effect. We draw the conclusion that a brand with high level of environmental innovation can adopt atypical strategy and obtain competitive advantage. However, license effect does not work in some cases when customers construe these atypical strategies deviated from marketing convention as behavior sacrificing their personal benefit for other stakeholders' interest (like firms' and public interest in recycling strategy condition). By introducing license effect, we contribute to literature by bridging innovation literature and customer-based brand equity theory and exploring firms' benefit from consumers' evaluations. Furthermore, our findings remind managers of a new approach, employing a typical strategy to achieve competitive advantages, to improve return from environmental innovation investment. Further research could test license effect in a long-term effect, verify the influence of other factors on license effect, and examine license effect on other strategies.

\section{Acknowledgements}

This work was supported by MOE (Ministry of Education in China) Project of Humanities and Social Sciences [Grant No. 15YJA630089].

\section{References}

[1] Reid, A. and Miedzinski, M. (2008) Eco-Innovation: Final Report for Sectoral Innovation Watch. Systematic Eco-Innovation Report, 1-3.

[2] Peng, X., Liu, Y. and Zhao, L. (2014) A Literature Review of Corporate Eco-Innovation: Theoretical Veins, Concept Clarification and Measurement. Acta Ecologica Sinica, 34, 6440-6449.

[3] Azevedo, S.G., Brandenburg, M., Carvalho, H. and Cruz-Machado, V. (2014) EcoInnovation and the Development of Business Models. Springer International Publishing, Cham, 32, 10-17. https://doi.org/10.1007/978-3-319-05077-5

[4] Triebswetter, U. and Wackerbauer, J. (2008) Integrated Environmental Product Innovation in the Region of Munich and Its Impact on Company Competitiveness. Journal of Cleaner Production, 16, 1484-1493. https://doi.org/10.1016/j.jclepro.2007.09.003

[5] Schiederig, T., Tietze, F. and Herstatt, C. (2012) Green Innovation in Technology and Innovation Management-An Exploratory Literature Review. $R$ \& D Management, 42, 180-192. https://doi.org/10.1111/j.1467-9310.2011.00672.x

[6] Hart, S.L. (1995) A Natural Resource-Based View of the Firm. Academy of Management Review, 20, 986-1014.

[7] Kesidou, E. and Demirel, P. (2012) On the Drivers of Eco-Innovations: Empirical Evidence from the UK. Research Policy, 41, 862-870. https://doi.org/10.1016/j.respol.2012.01.005

[8] Medeiros, P.M. (2013) Why Is Change Feared? Exotic Species in Traditional Pharmacopoeias. Ethnobiology \& Conservation, 2, 1-5.

[9] Lee, K.H. and Min, B. (2015) Green R \& D for Eco-Innovation and Its Impact on Carbon Emissions and Firm Performance. Journal of Cleaner Production, 108, 534 542. https://doi.org/10.1016/j.jclepro.2015.05.114

[10] Przychodzen, J. and Przychodzen, W. (2015) Relationships between Eco-Innovation and Financial Performance-Evidence from Publicly Traded Companies in Poland 
and Hungary. Journal of Cleaner Production, 90, 253-263.

https://doi.org/10.1016/j.jclepro.2014.11.034

[11] Yadav, M., Généreux, P., Palmerini, T., Caixeta, A., Madhavan, M.V., Xu, K., et al. (2015) Syntax Score and the Risk of Stent Thrombosis after Percutaneous Coronary Intervention in Patients with Non-st-Segment Elevation Acute Coronary Syndromes: An Acuity Trial Substudy. Catheterization and Cardiovascular Interventions, 85, 1-10. https://doi.org/10.1002/ccd.25396

[12] Barone, M.J. and Jewell, R.D. (2014) How Brand Innovativeness Creates Advertising Flexibility. Journal of the Academy of Marketing Science, 42, 309-321. https://doi.org/10.1007/s11747-013-0352-7

[13] Barone, M.J. and Jewell, R.D. (2013) The Innovator's License: A Latitude to Deviate from Category Norms. Journal of Marketing, 77, 120-134.

https://doi.org/10.1509/jm.10.0145

[14] Olsen, S., Chandukala, M.C., Slotegraaf, R.J. and Chandukala, S.R. (2014) Green Claims and Message Frames: How Green New Products Change Brand Attitude. Journal of Marketing, 78, 119-137. https://doi.org/10.1509/jm.13.0387

[15] Berrone, P., Fosfuri, A., Gelabert, L. and Gomez-Mejia, L.R. (2013) Necessity as the Mother of "Green" Inventions: Institutional Pressures and Environmental Innovations. Strategic Management Journal, 34, 891-909. https://doi.org/10.1002/smj.2041

[16] Bönte, W. and Dienes, C. (2013) Environmental Innovations and Strategies for the Development of New Production Technologies: Empirical Evidence from Europe. Business Strategy and the Environment, 22, 501-516. https://doi.org/10.1002/bse.1753

[17] Philippe, D. and Durand, R. (2011) The Impact of Norm-Conforming Behaviors on Firm Reputation. Strategic Management Journal, 32, 969-993. https://doi.org/10.1002/smj.919

[18] Buysse, K. and Verbeke, A. (2003) Environmental Strategy Choice and Financial Profitability: Differences between Multinationals and Domestic Firms in Belgium. Research in Global Strategic Management, 9, 43-63. https://doi.org/10.1016/S1064-4857(03)09003-X

[19] Kammerer, D. (2009) The Effects of Customer Benefit and Regulation on Environmental Product Innovation: Empirical Evidence from Appliance Manufacturers in Germany. Ecological Economics, 68, 2285-2295. https://doi.org/10.1016/j.ecolecon.2009.02.016

[20] Bendell, B.L. (2015) I Don't Want to Be Green: Prosocial Motivation Effects on Firm Environmental Innovation Rejection Decisions. Journal of Business Ethics, 143, 277-288.

[21] Keller, K.L. (1993) Conceptualizing, Measuring and Managing Customer Based Brand Equity. Journal of Marketing, 57, 1-22. https://doi.org/10.2307/1252054

[22] Keller, K.L. and Aaker, D.A. (1992) The Effects of Sequential Introduction of Brand Extensions. Journal of Marketing Research, 29, 35-50. https://doi.org/10.2307/3172491

[23] Sriram, S. and Kalwani, M.U. (2007) Monitoring the Dynamics of Brand Equity using Store-Level Data. Journal of Marketing, 71, 61-78. https://doi.org/10.1509/jmkg.71.2.61

[24] Brown, T.J. and Dacin, P.A. (1997) The Company and the Product: Corporate Associations and Consumer Product Responses. Journal of Marketing, 61, 68-84. https://doi.org/10.2307/1252190

[25] Berens, G., Riel, C.B.M.V. and Bruggen, G.H.V. (2005) Corporate Associations and 
Consumer Product Responses: The Moderating Role of Corporate Brand Dominance. Journal of Marketing, 69, 35-48. https://doi.org/10.1509/jmkg.69.3.35.66357

[26] Shrivastava, P. (1995) Environmental Technologies and Competitive Advantage. Strategic Management Journal, 16, 183-200.

https://doi.org/10.1002/smj.4250160923

[27] Rennings, K. (2000) Redefining Innovation-Eco-Innovation Research and the Contribution from Ecological Economics. Ecological Economics, 32, 319-332. https://doi.org/10.1016/S0921-8009(99)00112-3

[28] Pujari, D. (2006) Eco-Innovation and New Product Development: Understanding the Influences on Market Performance. Technovation, 26, 76-85.

https://doi.org/10.1016/j.technovation.2004.07.006

[29] Gershoff, A.D. and Frels, J.K. (2015) What Makes It Green? The Role of Centrality of Green Attributes in Evaluations of the Greenness of Products. Journal of Marketing, 79, 97-110. https://doi.org/10.1509/jm.13.0303

[30] Barbarossa, C. and Pelsmacker, P.D. (2016) Positive and Negative Antecedents of Purchasing Eco-Friendly Products: A Comparison between Green and Non-Green Consumers. Journal of Business Ethics, 134, 229-247. https://doi.org/10.1007/s10551-014-2425-z

[31] Jung, H.J., Kim, H.J. and Oh, K.W. (2016) Green Leather for Ethical Consumers in China and Korea: Facilitating Ethical Consumption with Value-Belief-Attitude Logic. Journal of Business Ethics, 135, 1-20. https://doi.org/10.1007/s10551-014-2475-2

[32] Marchi, V.D., Maria, E.D. and Micelli, S. (2013) Environmental Strategies, Upgrading and Competitive Advantage in Global Value Chains. Business Strategy and the Environment, 22, 62-72. https://doi.org/10.1002/bse.1738

[33] Carrillo-Hermosilla, J., Río González, P.D. and Könnöla, T. (2009) Eco-Innovation: When Sustainability and Competitiveness Shake Hands. Palgrave Macmillan, London, 1-13. https://doi.org/10.1057/9780230244856

[34] Li, X., Bai, R. and Mckechnie, J. (2016) Environmental and Financial Performance of Mechanical Recycling of Carbon Fibre Reinforced Polymers and Comparison with Conventional Disposal Routes. Journal of Cleaner Production, 127, 451-460. https://doi.org/10.1016/j.jclepro.2016.03.139

[35] Baxter, J., Lyng, K.A., Askham, C. and Hanssen, O.J. (2016) High-Quality Collection and Disposal of WEEE: Environmental Impacts and Resultant Issues. Waste Management, 57, 17-26. https://doi.org/10.1016/j.wasman.2016.02.005

[36] Kang, H.Y., Schoenung, J.M., Kang, H.Y. and Schoenung, J.M. (2005) Electronic Waste Recycling: A Review of U.S. Infrastructure and Technology Options. Resources Conservation \& Recycling, 45, 368-400. https://doi.org/10.1016/j.resconrec.2005.06.001

[37] Guide, V.D.R., Souza, G.C., Wassenhove, L.N.V. and Blackburn, J.D. (2004) Time Value of Commercial Product Returns. Management Science, 52, 1200-1214. https://doi.org/10.1287/mnsc.1060.0522

[38] Troschinetz, A.M. and Mihelcic, J.R. (2009) Sustainable Recycling of Municipal Solid Waste in Developing Countries. Waste Management, 29, 915-923. https://doi.org/10.1016/j.wasman.2008.04.016

[39] Awasthi, A.K., Zeng, X. and Li, J. (2016) Environmental Pollution of Electronic Waste Recycling in India: A Critical Review. Environmental Pollution, 211, 259270. https://doi.org/10.1016/j.envpol.2015.11.027

[40] Wang, Z., Guo, D. and Wang, X. (2016) Determinants of Residents' E-Waste Recy- 
cling Behaviour Intentions: Evidence from China. Journal of Cleaner Production, 137, 850-860. https://doi.org/10.1016/j.jclepro.2016.07.155

[41] Cui, J. and Zhang, L. (2008) Metallurgical Recovery of Metals from Electronic Waste: A Review. Journal of Hazardous Materials, 158, 228-256.

https://doi.org/10.1016/j.jhazmat.2008.02.001

[42] Peattie, K. (2001) Golden Goose or Wild Goose? The Hunt for the Green Consumer. Business Strategy and the Environment, 10, 187-199. https://doi.org/10.1002/bse.292

[43] Grimmer, M. and Woolley, M. (2012) Green Marketing Messages and Consumers' Purchase Intentions: Promoting Personal versus Environmental Benefits. Journal of Marketing Communications, 20, 231-250. https://doi.org/10.1080/13527266.2012.684065

[44] Kahneman, D. and Thaler, R. (1986) Fairness as a Constraint on Profit Seeking: Entitlements in the Market. American Economic Review, 76, 728-741.

[45] Gu, Q., Ji, J. and Gao, T. (2008) Pricing Management for a Closed-Loop Supply Chain. Journal of Revenue and Pricing Management, 7, 45-60.

https://doi.org/10.1057/palgrave.rpm.5160122

[46] Nagurney, A. and Toyasaki, F. (2005) Reverse Supply Chain Management and Electronic Waste Recycling: A Multitiered Network Equilibrium Framework for ECycling. Transportation Research Part E Logistics \& Transportation Review, 41, 128. https://doi.org/10.1016/j.tre.2003.12.001 